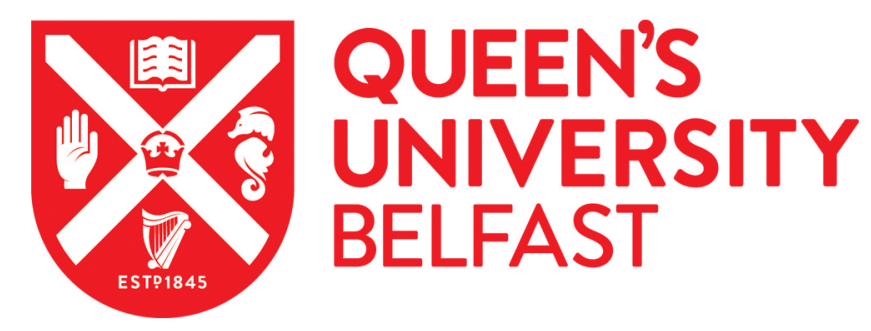

\title{
Correlation analysis as a tool to investigate the bioaccessibility of nickel, vanadium and zinc in Northern Ireland soils
}

Palmer, S., Ofterdinger, U., McKinley, J. M., Cox, S., \& Barsby, A. (2013). Correlation analysis as a tool to investigate the bioaccessibility of nickel, vanadium and zinc in Northern Ireland soils. Environmental Geochemistry and Health, 35(5), 569-584. https://doi.org/10.1007/s10653-013-9540-0

Published in:

Environmental Geochemistry and Health

Document Version:

Peer reviewed version

Queen's University Belfast - Research Portal:

Link to publication record in Queen's University Belfast Research Portal

Publisher rights

○ Springer International Publishing AG

The final publication is available at Springer via http://link.springer.com/article/10.1007\%2Fs10653-013-9540-0

\section{General rights}

Copyright for the publications made accessible via the Queen's University Belfast Research Portal is retained by the author(s) and / or other copyright owners and it is a condition of accessing these publications that users recognise and abide by the legal requirements associated with these rights.

Take down policy

The Research Portal is Queen's institutional repository that provides access to Queen's research output. Every effort has been made to ensure that content in the Research Portal does not infringe any person's rights, or applicable UK laws. If you discover content in the Research Portal that you believe breaches copyright or violates any law, please contact openaccess@qub.ac.uk. 


\section{CORRELATION ANALYSIS AS A TOOL TO INVESTIGATE THE BIOACCESSIBILITY OF NICKEL, VANADIUM AND ZINC IN NORTHERN IRELAND SOILS}

Sherry Palmer ${ }^{a,}$, , Ulrich Ofterdinger ${ }^{a}$, Jennifer M. McKinley ${ }^{b},{\text { Siobhan } \operatorname{Cox}^{a} \text { and }}$ Amy Barsby ${ }^{b, \neq}$

${ }^{a}$ EERC, School of Planning, Architecture and Civil Engineering, Queen's University Belfast, Belfast, BT9 5AG, UK

${ }^{b}$ School of Geography, Archaeology and Palaeoecology, Queen's University Belfast, BT7 1NN, UK

*Corresponding author

Tel.: +44(0)289097 5606, Fax: +44(0)2890974278

E-mail: spalmer04@qub.ac.uk

${ }^{\ddagger}$ posthumously

Keywords: Bioaccessibility, geogenic contamination, geochemistry, trace elements, human health risk assessment

Abstract: Correlation analyses were conducted on nickel (Ni), vanadium (V) and zinc $(\mathrm{Zn})$ oral bioaccessible fractions (BAFs) and selected geochemistry parameters to identify specific controls exerted over trace element bioaccessibility. BAFs were determined by previous research using the Unified BARGE Method. Total trace element concentrations and soil geochemical parameters were analysed as part of the Geological Survey of Northern Ireland Tellus Project. Correlation analysis included Ni, V and Zn BAFs against their total concentrations, $\mathrm{pH}$, estimated soil organic carbon (SOC) and a further eight element oxides. BAF data were divided into three separate generic bedrock classifications of basalt, lithic arenite and mudstone prior to analysis, resulting in an increase in average correlation coefficients between BAFs and geochemical parameters. Sulphur trioxide and SOC, spatially correlated with upland peat soils, exhibited significant positive correlations with all BAFs in gastric and gastrointestinal digestion phases, with such effects being strongest in the lithic arenite bedrock group. Significant negative relationships with bioaccessible $\mathrm{Ni}, \mathrm{V}$ and $\mathrm{Zn}$ and their associated total concentrations were observed for the basalt group. Major element oxides were associated with reduced oral trace element bioaccessibility, with $\mathrm{Al}_{2} \mathrm{O}_{3}$ resulting in the highest number of significant negative correlations followed by $\mathrm{Fe}_{2} \mathrm{O}_{3}$. Spatial mapping showed that metal oxides were present at reduced levels in peat soils. The findings illustrate how specific geology and soil geochemistry exert controls over trace element bioaccessibility, with soil chemical factors having a stronger influence on BAF results than relative geogenic abundance. In general, higher $\mathrm{Ni}, \mathrm{V}$ and $\mathrm{Zn}$ bioaccessibility is expected in peat soil types. 
54 Determining the bioaccessibility of potentially toxic elements in soil provides 55 supporting information to more accurately constrain human health risk assessment 56 approaches where oral soil borne contaminant exposure is the pathway of concern.

57 While much research has been conducted in terms of the bioavailability and 58 bioaccessibility of trace elements such as lead and arsenic, particularly from 59 anthropogenic sources (Farmer et al. 2011; Meunier et al. 2010; Palumbo-Roe and 60 Klinck 2007), a knowledge gap exists concerning the bioaccessibility of a wider 61 range of metals and metalloids from geogenic sources.

63 Previous research suggests that toxic elements from geogenic sources may be less 64 bioaccessible than those associated with anthropogenic contamination due to the 65 solid phases in which they exist (Cave et al. 2007; Cave et al. 2003). Such 66 findings have implications for human health risk assessments in the context of the 67 United Kingdom's (UK) contaminated land legislation regime (DEFRA 2012), as 68 better determination of specific health risks could avoid unnecessary soil 69 remediation projects. In addition, correlating trace element abundance and 70 bioaccessibility to specific soil types, geochemical parameters and parent bedrock 71 geology can identify natural controls exerted over the bioavailability of geogenic 72 contaminants, facilitating more accurate site-specific risk assessments.

74 In Northern Ireland, nickel (Ni), vanadium (V) and zinc ( $\mathrm{Zn})$, whose distributions 75 are largely controlled by local geology, are present in soils at elevated levels, 76 exceeding either Environment Agency (EA) Soil Guideline Values (SGVs) or 77 other existing available generic assessment criteria (Barsby et al. 2012; EA 2009a; 78 Nathanail et al. 2009). However, assessment criteria must be used with care, and 79 particular attention should be paid to the derivation of such guideline values. For 80 example, arsenic health criteria values and subsequent SGVs have been derived 81 using toxicology data from exposure to soluble forms of arsenic in drinking water 82 rather than from exposure via soil media (EA 2009b; EA 2009c). Where Ni is 83 concerned, the inhalation pathway is considered to be the most significant 84 exposure route capable of introducing human health risks, although toxicological 85 information suggests some forms of $\mathrm{Ni}$ are still readily absorbed through the 
gastro-intestinal tract when ingested and, therefore, still capable of inducing toxic

87 health effects (EA 2009a; EA 2009d). Such challenges regarding the accurate characterization of risks associated with soil-borne trace element exposure highlight the need for employing more detailed assessment techniques such as

90 bioaccessibility testing, thus ensuring exposure pathways are relevant to specific

91 toxic effects, land use scenarios and contaminant sources.

93 In response to these issues, much research has been conducted over the past two 94 decades in order to refine a suitable methodology for bioaccessibility testing 95 where ingestion of soil is the exposure pathway of concern (Wragg et al. 2011; 96 Wragg et al. 2009; Wragg and Cave 2003; Van de Weile et al. 2007; Oomen et al. 97 2003; Ruby et al. 1999; Ruby et al. 1996). The most recently published 98 methodology widely in use in the UK and European Union to date, the Unified 99 BARGE (BioAccessibility Research Group of Europe) Method (UBM), has been 100 validated against in vivo data for arsenic, cadmium and lead (Denys et al. 2012; 101 BARGE/INERIS 2010; Caboche 2009). A recently published study by Barsby et 102 al. (2012) was the first bioaccessibility investigation of its kind covering the 103 region of Northern Ireland and employing the UBM. The findings of this study 104 suggested that trace element bioaccessibility was specific to individual geologic 105 formations within the region, thus unveiling a wider scope of investigation for 106 determining in more detail the mechanisms governing this variability.

108 Specific soil properties such as redox potential, parent rock material, organic 109 content, $\mathrm{pH}$, nutrient content, and the co-occurrence of major element oxides can 110 influence the mobility and bioavailability of toxic elements in soil. For example, 111 Poggio et al. (2009) found soil organic matter was positively correlated with the 112 bioaccessibility of several trace metals, including $\mathrm{Ni}$ and $\mathrm{Zn}$. Where $\mathrm{Zn}$ is 113 concerned, decreased bioaccessibility has been associated with the presence of 114 aluminium oxides, and its mobility and resulting bioaccessibility may also be 115 affected by the presence of organic matter (Pelfrêne et al. 2012; Nathanial et al. 116 2009; Poggio et al. 2009; ATSDR 2005). Less information is available to date 117 concerning such relationships for $\mathrm{V}$, although acidic $\mathrm{pH}$ has been found to reduce 118 its mobility in soil (Nathanail et al. 2009), which is in contrast to other trace 119 metals where solubility generally increases under acid soil conditions. Chemical 
120 conditions that are conducive to increased element mobility and solubility will in

121 turn enhance bioaccessibility.

123 The aim of this paper is to illustrate how geology and geochemistry influence

124 trace element bioaccessibility by using correlation analyses to identify 125 relationships between $\mathrm{Ni}, \mathrm{V}$ and $\mathrm{Zn}$ bioaccessible fractions (BAFs) in soil and 126 selected geochemistry variables. With Northern Ireland's diverse geology, 127 unsurpassed by any other country of a similar size (Jordan et al. 2007; Mitchell 128 2004; Wilson 1972), such a study has wider applications beyond the immediate 129 study area when conducting site-specific human health risk assessments.

131 2. Methodology

\section{$133 \quad 2.1$ Study Area}

135 The range of bedrock types encountered in Northern Ireland forms a stratigraphic 136 record which commences in the Mesoproterozoic era, comprising deformed and 137 metamorphosed sedimentary and volcanic rocks formed at least 600 million years 138 ago (Mitchell 2004). The region includes examples of all geological systems up 139 to and including the Palaeogene period, comprising basalt lavas and lacustrine 140 sedimentary rocks formed between circa 55 and 62 million years ago. Quaternary 141 processes involved the advance of ice sheets and their meltwaters, resulting in a 142 range of diverse superficial deposits including glacial till. As a result, superficial 143 deposits such as glacial till and post-glacial alluvium cover at least $80 \%$ of 144 bedrock in the region. The rock types encountered find stratigraphic distribution 145 beyond Northern Ireland and, thus, findings in relation to pedological and 146 geological controls on trace element bioaccessibility associated with specific soil 147 and rock geochemical signatures has applications beyond the immediate region of 148 Northern Ireland.

150 Data associated with sample locations presented for this study are divided into 151 three generic bedrock types: basalt, lithic arenite and mudstone (Fig. 1). The 152 rationale for selection of these groups is provided in Section 2.4. The basalt lavas 153 of the Antrim Plateau are located in the northeast of the study region, with lithic 
154 arenite sample locations occurring predominantly in the southeast in the County

155 Down area. In the southwest region of Fermanagh, sedimentary rock types are 156 present, classified generally as mudstones.

2.2 Geochemistry Analyses

160 The GSNI (Geological Survey of Northern Ireland) Tellus Survey, conducted 161 between 2004 and 2007, consisted of a comprehensive survey of stream sediments 162 and stream waters, as well as rural and urban soils. Composite rural soil samples used for this research were collected from a total of 6,862 locations on a $2 \mathrm{~km}^{2}$

164 grid from a depth of 5-20 cm below ground level (Smyth 2007).

166 Soil geochemistry data relating to trace elements, element oxides and other 167 geochemical parameters including $\mathrm{pH}$ and loss on ignition (LOI; \%) were 168 determined as detailed in the Tellus geochemical mapping methodology report 169 (Smyth 2007). Pseudo-total and total concentrations of Ni, V and $\mathrm{Zn}\left(\mathrm{mg} \mathrm{kg}^{-1}\right)$ 170 were determined both by aqua regia digestion followed by inductively coupled 171 plasma spectrometry (ICP), as well as by pressed pellet X-ray fluorescence 172 spectrometry (XRF). Major element oxides (\%) were determined also by XRF.

174 LOI, applied as an estimate of soil organic carbon (SOC), was determined by 175 calculating sample weight loss after oven drying at $105^{\circ} \mathrm{C}$ for 4 hours followed by 1764 hours in a $450^{\circ} \mathrm{C}$ furnace. While not a means of determining the precise carbon 177 content of soils, the LOI method is recognised as a suitable, cost-effective 178 approach to estimating regional trends in SOC and has been applied in other 179 published research (Salehi et al. 2011; Elzinga and Cirmo 2010; Konen et al. 180 2002; Ball 1964).

\section{$182 \quad 2.3$ Unified BARGE Method Testing}

184 The UBM is a sequential extraction technique designed to mimic the conditions of 185 the human digestive system. Three stages of the UBM aim to represent the 186 salivary, stomach and intestinal exposure conditions of an ingested material. Two 187 extracts are collected from the method: one following a one hour gastric digestion 
188 using synthesised saliva and stomach fluids, and a second extract is obtained after

189 an additional four hours of gastro-intestinal digestion using synthesised duodenal

190 fluid and bile. Details of the UBM protocol and required equipment and reagents

191 are available on the BARGE web site (BARGE/INERIS 2010). UBM laboratory

192 work was carried out at the British Geological Survey (BGS) in Keyworth,

193 Nottingham. Methodology and quality control efforts used to obtain the

194 bioaccessibility data referred to in this paper have been published previously

195 (Barsby et al. 2012). For every 10 samples analysed by the UBM, one duplicate,

196 one blank and one reference soil (BGS 102; Wragg et al. 2009) were extracted.

198 As described in Barsby et al. (2012), the trace element oral bioaccessibility was 199 determined on a subset of archived surface soil samples from the original rural 200 soil sampling programme of the GSNI Tellus Survey. Soil samples used for UBM 201 testing, comprising 91 samples in total, were chosen with the aim of representing 202 a broad spatial, lithological and pedological coverage across the region. Dried 203 and sieved soil from the $<250 \mu \mathrm{m}$ fraction was used for the UBM digestion.

205 Bioaccessible trace element concentrations were measured by inductively coupled 206 plasma mass spectrometry (ICP-MS) following gastric (G) and the gastro207 intestinal (GI) UBM extraction. BAFs (\%) were calculated using bioaccessible 208 concentrations determined from the UBM test $\left(C_{b}\right)$ and the total XRF 209 concentration in the soil sample as provided by the Tellus Survey data base $\left(C_{p t}\right)$. 210

$$
B A F[\%]=\frac{C_{b}\left[m g k g^{-1}\right]}{C_{p t}\left[m g k g^{-1}\right]} \times 100
$$

214 XRF total concentrations were chosen for BAF calculation instead of ICP pseudo215 total concentrations because of the ability of XRF analysis to detect insoluble 216 traces of elements, providing a better understanding of total trace element 217 bioaccessibility in terms of insoluble, geogenic mineral forms. Relative BAF 218 results (\%) were used for the correlation analyses as opposed to absolute UBM 
219 extract concentration values to provide a normalised basis for comparison of

220 relative trace element bioaccessibility across geologic sub-groups.

224 Correlation analyses were carried out using G- and GI-BAFs of the three trace 225 elements against the following geochemical variables: oxides of magnesium $226(\mathrm{MgO})$, aluminium $\left(\mathrm{Al}_{2} \mathrm{O}_{3}\right)$, silicone $\left(\mathrm{SiO}_{2}\right)$, sulphur $\left(\mathrm{SO}_{3}\right)$, phosphorous $\left(\mathrm{P}_{2} \mathrm{O}_{5}\right)$, 227 calcium $(\mathrm{CaO})$, manganese $(\mathrm{MnO})$, and iron $\left(\mathrm{Fe}_{2} \mathrm{O}_{3}\right)$; total $\mathrm{Ni}, \mathrm{V}$ and $\mathrm{Zn}$ 228 concentrations; SOC; and $\mathrm{pH}$. A two-tailed significance test was applied using 229 the Pearson's correlation coefficient $(r)$ in IBM SPSS Statistics v.19. Cut off 230 points for critical $r$ values were determined according to sample group sizes as 231 defined in Triola (1998).

233 Initial exploration of distribution trends in the Tellus geochemistry data set 234 indicated that, while all geochemistry data were not normally distributed when 235 tested for skewness and kurtosis, log-transformation of the data did not 236 substantially improve tendencies towards normal distributions. When Tellus 237 geochemistry data were divided into geologic sub-groups, the tendency towards a 238 normal distribution was increased. Parametric statistical testing was therefore 239 deemed suitable for the purpose of these analyses.

241 Correlation analyses were first conducted on the complete bioaccessibility study 242 set $(n=91)$. This sample set was subsequently divided into geologic sub-groups 243 according to three generic bedrock types present in the study set in the highest 244 proportions as defined by the GSNI Tellus Survey methodology (Smyth 2007). 245 This was carried out with the aim of controlling for geogenic influences in the 246 geochemistry data and reducing potential sources of variance which could be 247 introduced from other soil properties or multiple rock types (Jordan et al. 2007; 248 Zhang et al. 2007). In turn, it was anticipated that the likelihood of identifying 249 geogenic controls over the BAF results would increase and correlation findings 250 would be strengthened. 
252 The rationale for using generic bedrock types as defined in the GSNI Tellus

253 Survey rather than specific local formations was to ensure statistical robustness

254 was maintained through the formation of sufficient sub-group sample sizes. The

255 three generic bedrock types present in the bioaccessibility study set in the highest

256 proportions were identified as basalt $(n=23)$, consisting of Upper and Lower

257 Basalt formations, the Tardree Rhyolite Complex, the Causeway Tholeiite

258 Member, and the Slieve Gullion Complex; lithic arenite $(n=17)$, inclusive of

259 Gilnahirk, Gala and Hawick Sandstones; and the mudstone group $(n=18)$,

260 represented by a mixture of sedimentary bedrock types including clays,

261 limestones, mudstones and shales.

262

\subsection{Spatial Data Analysis}

265 Spatial interpolation by inverse distance weighting (IDW) was applied to the

266 Tellus XRF geochemistry data set to illustrate geographic patterns in specific 267 spatial variables of interest. Mapped outputs of total toxic trace element 268 concentrations are presented in Barsby et al. (2012). IDW is a deterministic 269 method, resulting in a clustering of values around data points on the surface 270 through exact interpolation (Lloyd 2010). This effect is reduced in regularly 271 gridded data such as the Tellus data used for this study. The IDW method 272 assumes that sample points further away spatially will have a diminished

273 influence over the interpolated value at a given location, while points closer to a 274 specific location will have a greater influence over its predicted value (ESRI 275 2010; Matheron 1965).

277 ArcGIS v.10 was used to map the spatial distribution of selected geochemical 278 variables from the complete Tellus geochemistry database $(n=6862)$ using IDW 279 with a power function of 2, a variable search radius and an output cell size of 250.

280 An iterative process was used to select the best fit model from four different 281 possible single-sector search neighbourhoods of $8,10,12$ or 15 neighbours. The 282 function resulting in the best fit regression model of prediction was chosen based 283 on values of mean prediction error, root mean square error and the slope of the 284 regression function. 
288 When average BAF results were compared across the three generic bedrock types, 289 differences in relative trace element bioaccessibility were observed (Table 1).

290 The highest measured mean and maximum G-BAF for V was in the basalt group.

291 However, the mean GI-BAF was greatest in the mudstone group. Zn G-BAF 292 averages were also higher in soil samples located over basalt bedrock types, while 293 differences in mean GI-BAFs were negligible, with the exception of the lithic 294 arenite bedrock group where the lowest Zn GI-BAF was observed. Both mean G295 and GI-BAF results for Ni were highest in the mudstone bedrock group, although 296 the maximum G- and GI-BAFs occurred in soil samples collected over basalt and 297 lithic arenite, respectively. The basalt group also displayed minimum G- and GI298 BAFs where Ni was concerned.

300 Table 2 provides a summary of Pearson's correlation coefficients $(r)$ for selected 301 geochemical parameters and UBM BAF data. In general, total trace element 302 concentrations were associated with reduced BAFs in the basalt sample group. 303 The same trend was apparent for $\mathrm{MgO}, \mathrm{MnO}, \mathrm{P}_{2} \mathrm{O}_{5}$ and $\mathrm{Fe}_{2} \mathrm{O}_{3}$ within this bedrock 304 group, with $\mathrm{P}_{2} \mathrm{O}_{5}$ revealing significant negative correlations to $\mathrm{Ni}, \mathrm{V}$ and $\mathrm{Zn} \mathrm{BAFs}$ 305 in the basalt samples only. $\mathrm{Al}_{2} \mathrm{O}_{3}$ showed strong negative influences over all trace 306 element BAFs, particularly for the basalt and mudstone samples. The effect of 307 silicates expressed in the form of $\mathrm{SiO}_{2}$ was less pronounced in terms of number of 308 significant correlations; however, where this oxide was significantly correlated 309 with $\mathrm{Ni}, \mathrm{V}$ and $\mathrm{Zn}$ BAFs, it appeared to exert a negative control over 310 bioaccessibility primarily in the gastric digestion phase. While $\mathrm{SO}_{3}$ and $\mathrm{SOC}$ 311 were consistently positively correlated with gastric BAFs, their effects were 312 strongest across both digestion phases in the lithic arenite bedrock group.

$314 \quad 3.1$ Vanadium

316 When V BAF results were analysed for correlations with other geochemical 317 properties within the bioaccessibility study sample set, significant negative 318 correlations were found between gastric $\mathrm{BAFs}$ and $\mathrm{MgO}, \mathrm{Al}_{2} \mathrm{O}_{3}, \mathrm{SiO}_{2}, \mathrm{MnO}$, and $319 \mathrm{Fe}_{2} \mathrm{O}_{3}(p \leq 0.01)$. Positive G-BAF relationships were observed with $\mathrm{SO}_{3}$ and 
320 SOC, also at the 0.01 significance level. Different effects on V BAFs were

321 apparent in the correlation data when gastro-intestinal BAFs were analysed. GI-

322 BAFs decreased in line with increasing total $\mathrm{V}$ and $\mathrm{Ni}$ content. $\mathrm{MgO}, \mathrm{MnO}$,

$323 \mathrm{Fe}_{2} \mathrm{O}_{3}$ and $\mathrm{Al}_{2} \mathrm{O}_{3}$ continued to exert negative effects over $\mathrm{V}$ BAFs in the gastro-

324 intestinal digestion phase, although the trend with $\mathrm{SiO}_{2}$ observed in the gastric

325 digestion phase was weakened to a point of non-significance. $\mathrm{SO}_{3}$ and $\mathrm{SOC}$

326 exhibited a significant positive relationship with V GI-BAFs $(p \leq 0.01)$, although

327 Pearson's correlation coefficients were reduced when compared to the G-BAF 328 data.

330 When BAFs were split into specific Tellus geology classifications, a number of 331 previously observed correlations changed. Average absolute $r$ values for G-BAFs 332 against geochemical parameters were $0.58,0.35$ and 0.38 for the basalt, lithic 333 arenite and mudstone groups, respectively, compared to an average correlation 334 coefficient of 0.31 when correlations were conducted on the complete study set. 335 Average absolute $r$ values for GI-BAF correlations doubled in the basalt group, 336 increased by 0.10 in the lithic arenite bedrock group, and improved by 0.16 in the 337 mudstone bedrock group when compared to statistics obtained from the full study 338 set prior to bedrock group division.

340 Overall, the greatest number of significant correlations between bioaccessible V 341 and geochemistry variables was observed in the basalt bedrock group. Both G342 and GI-BAFs were negatively correlated with total $\mathrm{V}, \mathrm{Ni}$ and $\mathrm{Zn}(p \leq 0.05)$. $343 \mathrm{MgO}, \mathrm{Al}_{2} \mathrm{O}_{3}, \mathrm{P}_{2} \mathrm{O}_{5}, \mathrm{MnO}$ and $\mathrm{Fe}_{2} \mathrm{O}_{3}$ also showed strong significant negative 344 correlations with bioaccessible $\mathrm{V}$ in the gastric and gastro-intestinal phases (-0.55 $345 \geq r \geq-0.77 ; p \leq 0.01)$. Increasing soil acidity appeared to result in increased $\mathrm{V}$ 346 bioaccessibility according to G- and GI-BAF correlation values. $\mathrm{SO}_{3}$ and $\mathrm{SOC}$ 347 exerted the strongest positive influence over gastric bioaccessible $\mathrm{V}$, although no 348 significant $r$ values were obtained for these variables within the basalt GI data.

350 The strongest negative correlations in soil samples overlying lithic arenite bedrock 351 were observed with $\mathrm{Al}_{2} \mathrm{O}_{3}$ and $\mathrm{Fe}_{2} \mathrm{O}_{3}$, while the highest positive correlations were 352 found with $\mathrm{SO}_{3}$ and $\mathrm{SOC}$. $\mathrm{SiO}_{2}$ also appeared to have a negative effect over G353 and GI-BAFs, though correlations were statistically significant in the gastric data 
354 only $(p \leq 0.05)$. Correlations in this bedrock group did not vary substantially

355 when gastric and gastro-intestinal digestion phases were compared.

357 In the mudstone bedrock group, $\mathrm{MgO}, \mathrm{Al}_{2} \mathrm{O}_{3}$ and $\mathrm{MnO}$ showed consistent 358 negative correlations with $\mathrm{V}$ BAFs in both the $\mathrm{G}$ and GI digestion phases. 359 Significant correlations were observed for $\mathrm{Fe}_{2} \mathrm{O}_{3}$ and $\mathrm{pH}$ in the GI-BAF data only.

360 In contrast to the inverse correlation observed between $\mathrm{pH}$ and $\mathrm{BAFs}$ in the basalt

361 bedrock group, positive correlation statistics were obtained across these variables 362 in the mudstone group.

3.2 Nickel

As shown in Table 2, bioaccessible Ni decreased in line with increasing total $\mathrm{V}$ 367 and $\mathrm{Ni}$, while the opposite was observed with total $\mathrm{Zn}$. Within the complete study 368 set, similar relationships were observed between Ni BAFs and oxides of $\mathrm{Mg}, \mathrm{Al}$, $369 \mathrm{Mn}$ and $\mathrm{Fe}$, as were found in the $\mathrm{V} \mathrm{BAF}$ data, with decreased levels of $\mathrm{Ni}$ 370 bioaccessibility associated with their occurrence. In addition to this trend, $\mathrm{SO}_{3}$ 371 and SOC continued to exert a positive influence over Ni G- and GI-BAF results, 372 with the largest $r$ values obtained for the gastric BAF data.

374 In the basalt group, the average Pearson's correlation coefficient was 0.68 and 3750.57 for the G- and GI-BAF data, respectively. Variables not producing 376 significant correlations in this group were $\mathrm{SiO}_{2}, \mathrm{SO}_{3}$ and $\mathrm{SOC}$, though this lack of 377 influence was observed within the gastro-intestinal data only. Total $\mathrm{Ni}, \mathrm{V}$ and $\mathrm{Zn}$ 378 were inversely correlated to Ni BAFs $(p \leq 0.01)$ in the basalt samples, while no 379 such significant relationships were found in the other two bedrock classes.

381 Although the number of significant correlations in the lithic arenite group 382 decreased when compared to the full study set results, average correlation 383 coefficients still increased slightly for both gastric and gastro-intestinal Ni BAFs. 384 This suggests the capability to identify correlations as significant was restricted 385 due to the reduced sub-sample size rather than being a result of weakened absolute $386 r$ values. Most notably in the lithic arenite group, $\mathrm{SO}_{3}$ and $\mathrm{SOC}$ showed strong 
387 positive correlations with G-BAF data ( $r=0.94$ and 0.81 , respectively), and also

388 with GI-BAF results ( $r=0.89$ and 0.65 , respectively; all $p \leq 0.01$ ).

390 The trends with sulphur trioxide and estimated organic content continued in the 391 mudstone group, while oxides of aluminium and silica appeared to result in 392 significantly reduced $\mathrm{Ni}$ bioaccessibility in the G-BAF data. The impact of $\mathrm{Al}_{2} \mathrm{O}_{3}$ 393 was still significant in the GI digestion phase $(p \leq 0.05)$, though this effect was 394 reduced when compared to the G-BAF results. $\mathrm{CaO}$ was significantly correlated 395 with Ni G-BAFs, with bioaccessibility appearing to increase in line with $\mathrm{CaO}$ 396 concentrations. This impact was not consistent across the geologic formations, 397 however, with significant negative correlations observed for this variable in the 398 basalt bedrock group.

$400 \quad 3.3$ Zinc

402 Overall, Zn exhibited the highest mean and maximum G- and GI-BAFs compared 403 to $\mathrm{Ni}$ and $\mathrm{V}$, with up to a quarter of total $\mathrm{Zn}$ found to be potentially bioaccessible 404 on average, reaching a maximum of $80 \%$ in the basalt group (Table 1). Following 405 a similar pattern to $\mathrm{V}$ and $\mathrm{Ni}$, oxides of $\mathrm{Mg}, \mathrm{Al}, \mathrm{Mn}$ and $\mathrm{Fe}$ were negatively 406 correlated to Zn BAFs in both the G and GI fractions. Total V and Ni were also 407 negatively correlated with bioaccessible $\mathrm{Zn}$ in the full study set; however, there 408 was a weak relationship between total and bioaccessible $\mathrm{Zn}$. $\mathrm{SO}_{3}$ and SOC 409 exhibited the strongest positive correlations with Zn G-BAFs, though significant 410 correlation coefficients were still obtained across the GI-BAF data (maximum $r=$ 411 0.95). $\mathrm{pH}$ was negatively correlated with Zn BAFs in the complete study set, and 412 this relationship was more clearly displayed within the basalt bedrock group.

413 However, this correlation was not significant in the other two bedrock groups ( $p \geq$ $4140.05)$.

416 In the basalt bedrock category, the only parameter not yielding a significant 417 correlation with $\mathrm{Zn} \mathrm{BAFs}$ was $\mathrm{SiO}_{2}$ in the gastro-intestinal phase. The number of 418 significant correlations was substantially reduced in the other two bedrock groups 419 by comparison, although correlations with $\mathrm{SOC}, \mathrm{SO}_{3}, \mathrm{Fe}_{2} \mathrm{O}_{3}$ and $\mathrm{Al}_{2} \mathrm{O}_{3}$ remained 420 strong overall. Additional significant negative correlations were observed 
421 between total $\mathrm{V}$, total $\mathrm{Ni}$ and $\mathrm{Zn}$ GI-BAFs in both the lithic arenite and mudstone 422 groups $(p \leq 0.05)$. $\mathrm{SiO}_{2}$ was associated with decreased gastric $\mathrm{Zn}$ bioaccessibility 423 across all sample sets, while $\mathrm{P}_{2} \mathrm{O}_{5}$ and $\mathrm{CaO}$ appeared to exert strong negative 424 effects over G- and GI-BAFs in the basalt group. In contrast, $\mathrm{P}_{2} \mathrm{O}_{5}$ and $\mathrm{CaO}$ 425 yielded weakly positive $r$ values in the mudstone bedrock group, although 426 statistical significance was limited to $\mathrm{CaO}$ and the gastric bioaccessible fraction $(r$ $427=0.76, p \leq 0.01)$.

\subsection{Spatial Trends}

431 As shown by the correlation analysis (Table 2), $\mathrm{SO}_{3}$ and SOC consistently exerted 432 positive controls over the bioaccessibility of the three trace elements. In addition, $433 \mathrm{SO}_{3}$ and SOC are strongly correlated to each other across Northern Ireland $(r=$ $4340.86, p \leq 0.01$ ). As shown by Fig. $2 \mathrm{c}$ and $\mathrm{d}, \mathrm{SO}_{3}$ and $\mathrm{SOC}$ share similar spatial 435 distributions across Northern Ireland, overlapping directly with the extent of acid 436 upland peat soils. Overall, the range of $\mathrm{pH}$ values in Northern Ireland soils is 437 relatively narrow (Fig. 2a), making definite correlations with BAF data difficult to 438 distinguish in the absence of a wider range of $\mathrm{pH}$ values. Although soil $\mathrm{pH}$ did 439 not appear as a factor affecting bioaccessibility as significantly as $\mathrm{SOC}$ and $\mathrm{SO}_{3}$

440 through the correlation analysis, more acidic soil conditions are shown to be well441 aligned spatially with peat soils in the region. In addition, spatial illustration of 442 the distribution of aluminium oxide (Fig. 2b), which exerted consistent negative 443 controls over $\mathrm{Ni}, \mathrm{V}$ and $\mathrm{Zn}$ BAFs, shows lower relative abundances in peaty 444 upland areas, with additional strong geologic controls over Al oxide distribution 445 around the Antrim Basalts in the northeast of the country. Interpolation of other 446 metal oxides associated with reduced BAFs such as $\mathrm{Fe}_{2} \mathrm{O}_{3}$ (not shown) resulted in 447 similar spatial distributions to $\mathrm{Al}_{2} \mathrm{O}_{3}$.

449 4. Discussion

4.1 Geogenic Sources of Variance

453 Correlation analysis is a useful tool for identifying relationships between pairs of 454 variables and for forming hypotheses on element sources, fate and behaviour. 
455 Such analyses can also support the development of mathematical models to 456 predict trace element bioaccessibility under certain conditions (Pelfrêne et al. 457 2012; Abollino et al. 2011; Poggio et al. 2009; Cave et al. 2007; Cave et al. 2003).

458 It is important to note, however, that correlation does not necessarily imply 459 causation (Triola 1998), and some of the geochemistry variables explored in this 460 study may be mere micro-scale indicators of wider scale factors or processes 461 bearing influence over trace element bioaccessibility. For example, some of the 462 oxides studied are used as indicators of rock and mineral weathering processes 463 which may be responsible for mobilising trace elements across large regional 464 scales.

466 While correlation analysis can assist with understanding specific mechanisms that 467 may influence trace element bioaccessibility, potential geogenic sources of 468 variance in geochemistry data should be eliminated before these relationships can 469 be effectively explored, particularly in Northern Ireland where such diversity in 470 geology exists (Jordan et al. 2007). The increase in average correlation 471 coefficients when the UBM data were split into the three dominant generic 472 bedrock types indicates that variability was reduced within the geologic sub473 groups. However, other sources of variability capable of weakening correlation 474 statistics are still present within these data sets. Soil type, for example, is a 475 variable that was not initially controlled for within the bedrock groups, although it 476 is a variable that was revealed during the course of analysis, in the case of peat.

477 At least eight distinctly different soil types are present within each of the basalt 478 and mudstone sample groups, while shale soil types dominated in the lithic arenite 479 division. Despite the variety of soil types in the basalt group, the high Pearson's 480 correlation coefficients for most parameters suggests that a large source of 481 variance in BAF data stems from geology in this area. Lower $r$ values in the other 482 bedrock groups suggest significant sources of variance are present in the results 483 not accounted for by bedrock type. For example, soil type or localised physico484 chemical factors such as soil moisture or redox conditions could also influence trace element mobility and bioaccessibility.

487 Differences in relative trace element bioaccessibility between the generic bedrock 488 groups (Table 1) may be attributed to $\mathrm{Ni}, \mathrm{V}$ or $\mathrm{Zn}$ existing in different solid 
489 phases over each bedrock type. For example, strong negative correlations

490 between trace element BAFs and their total concentrations in the basalt bedrock

491 group suggest most of the non-bioaccessible fraction of these elements is in an

492 insoluble form in these soils, with a lesser soluble component accounting for the

493 bioaccessible portion. This may be linked to the relative age of the basalt

494 formations, which are among the youngest and least weathered rocks in Northern

495 Ireland (Mitchell 2004). This conclusion is also supported by Cox et al. (2013),

496 whose analysis of the solid phase distributions of $\mathrm{Ni}$ from the same study area

497 found that soil samples containing greater proportions of $\mathrm{Ni}$ present in carbonate

498 phases also hosted more bioaccessible Ni. Conversely, soil samples containing

499 higher proportions of $\mathrm{Ni}$ hosted by Fe-oxides and clay had relatively lower $\mathrm{Ni}$

500 bioaccessibility. Previous comparison of ICP-derived trace element

501 concentrations against XRF data for the same elements suggests that the relative

502 solubilities of trace elements are influential in determining trace element

503 bioaccessibility, with XRF concentrations commonly higher than ICP data due to

504 the application of solvent-based aqua regia extraction versus the dry pellet 505 analytical technique used for the XRF analyses (Barsby et al. 2012). Weaker

506 negative correlations observed between BAFs and total trace element

507 concentrations in the mudstone and lithic arenite bedrock groups may be related to

508 their overall lack of relative abundance within these areas, illustrated previously

509 by Barsby et al. (2012). The exception to this trend is illustrated by $\mathrm{Zn}$ BAFs,

510 which were higher on average than the other two elements studied. Compared to

$511 \mathrm{Ni}$ and $\mathrm{V}, \mathrm{Zn}$ total distributions are controlled by a wider variety of rock types

512 other than basalt, with high relative concentrations also found in soils over

513 sandstone and limestone in the region.

515 While the overall trend in correlations with $\mathrm{pH}$ was weakly negative with respect

516 to trace element BAF data (Table 2), the mudstone group provided a consistent

517 exception to this result. A closer look at rock sub-types within this category 518 shows a mixture of limestone, clay, argillaceous rock and mudstone. The 519 presence of limestone in particular may have introduced variable results in the 520 laboratory due to the release of calcium carbonate into solution, creating unstable $521 \mathrm{pH}$ conditions during in vitro UBM extractions. $\mathrm{CaO}$ also showed a similar trend 522 to $\mathrm{pH}$ with respect to its variable influence over trace element BAFs, depending 
523 on how the data set was treated across the geologic classifications. Individual 524 trends in $\mathrm{CaO}$ correlations were aligned with $\mathrm{pH}$ trends within the basalt and 525 mudstone sample groups. Across Northern Ireland, $\mathrm{CaO}$ shows a significant positive correlation with $\mathrm{pH}(r=0.436, p \leq 0.01)$. With respect to BAF

527 correlation results, $\mathrm{CaO}$ and $\mathrm{pH}$ were both negatively correlated with $\mathrm{BAFs}$ in the 528 basalt group, but positively correlated with BAFs in the mudstone group. Both 529 basalt and limestone, included in the mudstone group, contribute to increased 530 levels of calcium in Northern Ireland soils (Jordan et al. 2001). However, 531 geogenic calcium in the basalt sample group may be in a less soluble form than 532 calcium found in limestone parent material. Chesworth et al. (1981) found that 533 the greatest proportion of calcium in basalt in Belbex, France was hosted by 534 pyroxene and plagioclase minerals which were the least susceptible to degradation 535 by weathering compared to other basalt minerals studied. This aligns with the 536 finding by Cox et al. (2013), whose XRD analysis of basalt mineralogy in County 537 Antrim, Northern Ireland confirmed the presence of the same weather and acid 538 resistant, calcium-rich minerals. Conversely, trace metals associated with high 539 carbonate soil components derived from calcium-rich parent material such as 540 limestone are easily extracted when exposed to acid conditions, resulting in 541 increased gastric bioaccessibility (Denys et al. 2007; Ljung et al. 2007; Nathanail 542 et al. 2007; Cave and Wragg 1997). Despite the common acceptance that $\mathrm{pH}$ is 543 largely influential over trace element bioaccessibility and mobility in the 544 environment, demonstrating such a mechanism through the statistical methods 545 applied here is difficult due to the highly controlled $\mathrm{pH}$ environment of UBM 546 laboratory methods (Pelfrêne et al. 2012; BARGE/INERIS 2010).

548 The relative abundances of co-occurring metal oxides were also associated with 549 increased variability in BAF results between the three groups, in particular where $550 \mathrm{Al}, \mathrm{Mg}, \mathrm{Mn}$ and $\mathrm{Fe}$ oxides are concerned. $\mathrm{Al}_{2} \mathrm{O}_{3}$ showed strong negative 551 influences over all trace element BAFs, particularly for the basalt and mudstone 552 samples. As shown by Fig. 2b, higher proportions of aluminium oxide in soil are 553 spatially correlated with basalt bedrock in the northeast of the region. 554 Additionally, aluminium compounds are expected to be higher in soils associated 555 with mudstone bedrock due to the clay content of soils from these parent materials 556 (Sparks 1995; Theng 1974). While the negative correlations found with 
557 aluminium oxide and $\mathrm{Ni}, \mathrm{V}$ and $\mathrm{Zn} \mathrm{BAFs}$ in this study may be due to geogenic or 558 pedological co-occurrence, aluminium, iron, manganese and other metal oxides 559 also participate in sorption and co-precipitation reactions capable of immobilising 560 heavy metal cations in soils (Pelfrêne et al. 2012; Laveuf et al. 2009; Cances et al 561 2008; Cave et al. 2007; Ma et al. 2007; ATSDR 2005; Flynn et al. 2003; Ruby et 562 al. 1999). In addition to chemically stabilising ionic forms of trace elements in 563 soils, the presence of co-occurring metals and their associated oxides may provide

564 an indication that trace elements are bound in insoluble solid phases of geogenic 565 origin (Wragg et al. 2007; Jordan et al. 2001; Ruby et al. 1999). When studying 566 the effects of weathering on element mobility in basalt, Chesworth et al. (1981) 567 found that $\mathrm{Al}$ and $\mathrm{Fe}$ weathering products precipitated into crystalline mineral 568 forms immediately after release from parent rock. In a study on the weathering 569 products of basalt in South China, Ma et al. (2007) concluded that Al and Fe 570 oxides and trace elements were mobilised during the weathering process, but 571 subsequently were removed deeper in the soil profile through the formation of 572 insoluble co-precipitates capable of encapsulating and storing trace elements. 573 Considering that soluble forms of trace metals are more bioaccessible than 574 insoluble ones, this supports the trend found in this study of reduced 575 bioaccessibility in the presence of $\mathrm{Al}_{2} \mathrm{O}_{3}$ and $\mathrm{Fe}_{2} \mathrm{O}_{3}$. However, more detailed 576 information is required about the precise mineral forms in which these oxides and 577 trace elements exist.

\subsection{Soil-Chemical Influences}

581 Beyond geogenic controls over trace element bioaccessibility, which are 582 important within wide spatial and time scales, more dynamic micro-scale 583 chemical processes should also be regarded as highly influential. Soil chemistry 584 including $\mathrm{pH}$, organic content, microbial processes, redox potential and cation 585 exchange capacity will significantly affect trace element bioaccessibility on 586 variable spatial and time scales, regardless of total element concentrations 587 (Abollino et al. 2011; Finžgar et al. 2007; Ljung et al. 2007; Hursthouse 2001). 588 The time scales over which these factors can influence bioaccessibility are 589 variable, with half-life sorption of metals onto humic materials in peat occurring 590 within a time scale as short as 5 seconds (Sparks 1995). Seasonal variations in 
591 soil moisture and resulting redox changes can also affect trace element

592 bioaccessibility and mobility, exemplifying the dynamic factors of influence that 593 occur outside of geologic time and spatial scales.

595 One of the most consistent positive influences identified over trace element 596 bioaccessibility was estimated soil carbon content. Poggio et al. (2009) found 597 similar positive correlations between oral bioaccessible $\mathrm{Ni}$ and $\mathrm{Zn}$ and soil 598 organic matter, and Nathanail et al. (2009) cite soil organic content as a key 599 consideration when assessing risks to human health from soil-borne contaminant 600 exposure. In contrast to these and previous findings, Pelfrêne et al. (2012) 601 concluded that SOC had a negative impact over gastric $\mathrm{Zn}$ bioaccessibility. 602 Despite this, the absence of organic matter deeper in the soil profile encourages $603 \mathrm{Al}$ and $\mathrm{Fe}$ to form insoluble co-precipitates with trace elements, while organic 604 compounds present at the soil surface may form organic colloids that increase 605 element mobility (Ma et al. 2007). Aluminium in particular freely moves from A 606 to B soil horizons in acidic podzol soil types that are rich in organic humic 607 material (Chesworth et al. 1981). Although the exact mechanisms by which SOC 608 increases element bioaccessibility cannot be determined from this study, it is 609 apparent that the presence of organic matter supports environmental conditions 610 that are conducive to higher levels of oral trace element bioaccessibility.

612 While the presence of higher amounts of soil carbon is positively correlated with 613 oral bioaccessibility results in this study, the effects of carbon in the human GI 614 tract may be contrary to the in vitro trend. Ruby et al. (1999) suggest that the 615 presence of organic matter in the form of food or soil particles in the GI tract may 616 hinder trace element transport across the intestinal epithelium, effectively 617 reducing trace element bioavailability. Further to this, organic matter has also 618 been found to influence trace element speciation in the stomach phase of UBM 619 digestion, which may in turn influence the final toxicity of an element after 620 ingestion (Broadway et al. 2010). Ljung et al. (2007) also point out that soluble 621 metals may be released from other compounds in the stomach acid, but that higher $622 \mathrm{pH}$ conditions in the intestine may cause insoluble precipitates to form, reducing 623 bioavailability prior to intestinal absorption. This observation may help explain 624 why correlation results for $\mathrm{BAFs}$ with $\mathrm{SO}_{3}$ and $\mathrm{SOC}$ were stronger in the stomach 
625 phase of digestion than the in the intestinal phase. It is also anticipated that 626 organic matter would be degraded to a high degree in the stomach acids, 627 potentially reducing the effects of this variable once digestate reaches the 628 intestinal phase.

630 Individual trace element chemistry and resulting behaviour in the environment 631 should also be considered where element mobility and bioaccessibility is 632 concerned. For example, higher $\mathrm{Zn}$ bioaccessibility when compared to $\mathrm{Ni}$ and $\mathrm{V}$ 633 may be associated with the tendency of $\mathrm{Zn}$ to commonly occur as a free ion in 634 natural systems (ATSDR 2005; CCME 1999). In a study of a suite of toxic metals 635 in soils, Poggio et al. (2009) also found that Zn bioaccessibility was higher when 636 compared to other metals studied. In nature, free $\mathrm{Zn}$ ions occur as $\mathrm{Zn}^{2+}$ which 637 readily participate in sorption reactions with negatively charged soil particles, $\mathrm{Fe}$ 638 and Mn oxides, clay minerals and organic matter. Low $\mathrm{pH}$ conditions discourage 639 such sorption mechanisms from taking place, while $\mathrm{Zn}$ precipitates will form 640 under alkaline conditions (Nathanail et al. 2009; ATSDR 2005; CCME 1999).

641 Although ionic sorption reactions have the ability to immobilise trace elements in 642 natural soil systems, such bonding mechanisms at the soil solution-particle 643 interface are driven by relatively weak forces. As a result, these bonds may be 644 easily broken by the acid conditions present in the human digestive system, re645 mobilising ions for GI uptake.

647 Correlations between sulphur and carbon content in Northern Ireland soils have 648 been explored previously by Jordan et al. (2001), where the narrow range of soil $649 \mathrm{pH}$ in the region was also observed. Peat soils possess many of the chemical 650 characteristics frequently associated with elevated trace element bioaccessibility. 651 Acidic and water-logged, reducing conditions erode soil parent material, 652 mobilising trace and major elements into soluble ionic forms (Elzinga and Cirmo 653 2010; Imrie et al. 2008; Finžgar, 2007). Some elements may then either be 654 leached out of the soil as a result, or retained by the high abundance of negatively 655 charged organic matter (CCME 1999; Guo et al. 1997). If this mobilising effect 656 causes major elements to be solubilised and subsequently leached, this renders 657 them unavailable for participation in sorption reactions with trace elements, which 658 may be the case where low abundance of metal oxides was observed in acid soils 
659 (Fig. 2). Further to this, the absence of oxygen under reducing conditions may 660 prevent the formation of metal oxides which require oxidative conditions (Wragg 661 et al. 2007). Another mechanism for decreased major element oxide 662 concentrations in water logged soils involves the biological and chemical 663 reduction of these oxides into insoluble sulphuric and organic precipitates (Guo et 664 al. 1997), where elements are effectively removed from soil solution and 665 prevented from engaging in further chemical reactions. This mechanism is 666 exacerbated in humus-rich peat soils, as organic matter has been found to prevent 667 the oxidative release of metals from other compounds (Hursthouse 2001). In 668 addition, acid $\mathrm{pH}$ conditions increase negative charges on organic soil particles, 669 more strongly retaining cations through sorption mechanisms and ligand exchange 670 (ATSDR 2005; Hursthouse 2001; Sparks 1995). This allows peat soils to 671 potentially act as a sink for storing more bioaccessible ionic forms of potentially 672 toxic elements.

674 Both Ni and $\mathrm{Zn}$ exhibit higher bioaccessibility in the presence of organic matter 675 and are also actively mobilised under acid conditions (EA 2009a; Nathanail et al. 676 2009; Poggio et al. 2009; Imrie et al. 2008), although less information is available 677 to clarify such trends for V. Nathanial et al. (2009) note that, unlike $\mathrm{Zn}$ and Ni, 678 acid $\mathrm{pH}$ generally immobilises $\mathrm{V}$ in soil solution, although this trend could not be 679 inferred from the data presented in this study. Previous mapping of the relative 680 spatial distributions of $\mathrm{Ni}, \mathrm{V}$ and $\mathrm{Zn}$ did not reveal higher trace element 681 concentrations in areas of upland peat, but were instead spatially controlled by 682 local geologic formations, particularly where basalt bedrock was present (Barsby 683 et al. 2012). This, combined with the spatial illustration and correlations found 684 with chemical parameters associated with peat soil types, suggests that total trace 685 element concentrations are not necessarily an indication of the actual health risk 686 present from toxic metal exposure. It can additionally be inferred that $\mathrm{Ni}, \mathrm{V}$ and $687 \mathrm{Zn}$ bioaccessibility is likely to be elevated in peat soil types. Due to the precise 688 geographic correlation of $\mathrm{SOC}$ and $\mathrm{SO}_{3}$ with peat soil across Northern Ireland and 689 the associated positive statistical correlations between $\mathrm{SOC}, \mathrm{SO}_{3}$ and trace 690 element bioaccessible fractions, it is concluded that peat soil types provide the 691 environmental conditions required to increase trace element mobility and 
692 bioaccessibility including acidic $\mathrm{pH}$, high chemical reduction potential, elevated

693 soil moisture and the presence of dissolved organic matter.

695 5. Conclusions

697 The strengthening of correlation statistics after division of BAF results into 698 generic geologic sub-groups suggests that substantial variance is introduced into a 699 data set when geochemistry is regarded collectively across a variety of rock 700 formations. Such grouping decreases this variance and allows the influence of 701 geology over trace element bioaccessibility to be more clearly exemplified.

702 Strong correlation statistics observed for the Antrim Basalts in particular suggest a 703 majority of variance in geochemistry and bioaccessibility is accounted for by the 704 local geology. Fewer statistically significant correlations in the other bedrock 705 groups indicate a higher degree of pedological or geogenic heterogeneity exists in 706 these areas, producing more variability in the results.

708 While relationships between the bioaccessible fractions of $\mathrm{Ni}, \mathrm{V}$ and $\mathrm{Zn}$ and other 709 variables have been explored through correlation analysis and limited mapping 710 techniques, a more detailed presentation of the landscape scale processes driving 711 these relationships would further compliment this research. In addition, analysing 712 UBM data in groups according to rock types that are more specific than the 713 generic Tellus bedrock classifications may give clearer indications of geologic 714 influences over trace element bioaccessibility and help further reduce variance in 715 the data sets.

717 Geochemical mapping combined with correlation analysis in this study shows that $718 \mathrm{Ni}, \mathrm{V}$ and $\mathrm{Zn}$ bioaccessibility is anticipated to be higher in peat soil types in 719 Northern Ireland and is not necessarily a function of total trace element 720 concentrations, which is the factor dominating the contaminated land risk 721 assessment regulatory regime in the United Kingdom.

723 Acknowledgements 
725 The authors would like to thank the Geological Survey of Northern Ireland for

726 supplying the necessary geochemical and spatial data for this research. UBM

727 testing at BGS Keyworth was funded by the BGS University Funding Initiative

728 (BUFI). The Tellus project was funded by the Northern Ireland Department of

729 Enterprise, Trade and Investment and by the Rural Development Programme

730 through the Northern Ireland Programme for Building Sustainable Prosperity.

731 The authors declare that they have no conflict of interest either with the funders of

732 this research or with the sponsors of this special edition.

References

Abollino, O., M. Maladrino, A. Giacomino and E. Mentasti (2011). The role of chemometrics in single and sequential extraction assays: A review Part I. Extraction procedures, uni- and bivariate techniques and multivariate variable reduction techniques for pattern recognition. Analytica Chimica Acta, 688, 104121.

Agency for Toxic Substances and Disease Registry (ATSDR) (2005). Toxicological Profile for Zinc. United States Department of Health and Human Services; Atlanta, GA.

Ball, D.F. (1964). Loss on ignition as an estimate of organic matter and organic carbon in non-calcareous soils. European Journal of Soil Science, 15(1), 84-92.

BARGE/INERIS (2010). UBM procedure for the measurement of inorganic contaminant bioaccessibility from solid matrices. Downloaded from Bioaccessibility Research Group of Europe home page on $26^{\text {th }}$ April, 2012.

Barsby, A., J. M. McKinley, U. Ofterdinger, M. Young, M. R. Cave, J. Wragg (2012). Bioaccessibility of trace elements in soils in Northern Ireland. Science of the Total Environment, 433, 398-417.

Broadway, A., M. R. Cave, J. Wragg, F. M. Fordyce, R. J. F. Bewley, M. C. Graham, B. T. Ngwenya and J. G. Farmer (2010). Determination of the bioaccessibility of chromium in Glasgow soil and the implications for human health risk assessment. Science of the Total Environment, 409, 267-277.

Caboche, J. (2009). Validation d'un test de mesure de bioaccessibilité. Application à quatre éléments traces métallique dans les sols: $\mathrm{As}, \mathrm{Cd}, \mathrm{Pb}$ et $\mathrm{Sb}$. Science Agronomique. PhD. L'Institut National Polytechnique de Lorraine, Nancy, pp. 348.

Canadian Council of Ministers of the Environment (CCME) (1999). Zinc. Canadian Soil Quality Guidelines for the Protection of Environmental and Human Health. 
771 Cances, B., F. Juillot, G. Morin, V. Laperche, D. Polya, D.J. Vaughan, J. L. 772 Hazemann, O. Proux, G. E. Brown Jr. and G. Calas (2008). Changes in arsenic 773 speciation through a contaminated soil profile: A XAS based study. Science of 774 the Total Environment, 397, 178-189.

775

776

777

778

779

780

Cave, M., H. Taylor and J. Wragg (2007). Estimation of the bioaccessible arsenic fraction in soils using near infrared spectroscopy. Journal of Environmental Science and Health Part A, 1293-1301.

Cave, M. R. and J. Wragg (1997). Measurement of trace element distributions in soils and sediments using sequential leach data and a non-specific extraction system with chemometric data processing. Analyst, 122, 1211-1221.

Cave, M. R., J. Wragg, B. Palumbo and B. A. Klinck (2003). Measurement of the bioaccessibility of arsenic in UK soils. Environment Agency R\&D Technical Report P5-062/TR02.

Chesworth, W., Jean Dejou and Pierre Larroque (1981). The weathering of basalt and relative mobilities of the major elements at Belbex, France. Geochimica et Cosmochimica Acta, 45, 1235-1243.

Cox, Siobhan F., Merlyn Chelliah, Jennifer M. McKinley, Sherry Palmer, Ulrich Ofterdinger, Michael Young, Mark R. Cave and Joanna Wragg (2013). "The importance of solid-phase distribution on the oral bioaccessibility of $\mathrm{Ni}$ and $\mathrm{Cr}$ in soils overlying Palaeogene basalt lavas, Northern Ireland." Environmental Geochemistry and Health, accepted manuscript in press.

Denys, S., J. Caboche, K. Tack and P. Delalain (2007). Bioaccessibility of lead in high carbonate soils. Journal of Environmental Science and Health Part A, 13311339.

Denys, S., J. Caboche, K. Tack, G. Rychen, J. Wragg, M. Cave, C. Jondreville and C. Feidt (2012). "In vivo validation of the unified BARGE method to assess the bioaccessibility of arsenic, antimony, cadmium and lead in soils." Environmental Science and Technology 46: 6252-6260.

Department for Environment, Food and Rural Affairs (DEFRA) (2012). Environmental Protection Act 1990: Part 2A. Contaminated Land Statutory Guidance. HM Government, Her Majesty's Stationery Office.

Environmental Systems Research Institute (ESRI) (2010). "How inverse distance weighted interpolation works." ArcGIS v.10 help files.

Elzinga, E. J., A. Cirmo (2010). Application of sequential extractions and X-ray absorption spectroscopy to determine the speciation of chromium in Northern New Jersey marsh soils developed in chromite ore processing residue (COPR). Journal of hazardous Materials, 183, 145-154.

Environment Agency (2009a). Soil guideline values for nickel in soil. Science Report SC050021/ Nickel SGV. 
Environment Agency (2009b). Soil guideline values for inorganic arsenic in soil.

Environment Agency (2009c). Contaminants in soil: updated collation of toxicological data and intake values for humans. Inorganic arsenic. Science report SC050021/TOX 1.

Environment Agency (2009d). Contaminants in soil: updated collation of toxicological data and intake values for humans. Nickel. Science report SC050021/TOX 8 .

Farmer, J. G., A. Broadway, M. R. Cave, J. Wragg, F. M. Fordyce, M. C. Graham, B. T. Ngwenya and R. J. F. Bewley (2011). A lead isotopic study of the human bioaccessibility of lead in urban soils from Glasgow, Scotland. Science of the Total Environment, 409, 4958-4965.

Finžgar, N., P. Tlustoš and D. Leštan (2007). Relationship of soil properties to fractionation, bioavailability and mobility of lead and zinc in soil. Plant Soil and Environment, 53, 225-238.

Flynn, H. C., A. A. Meharg, P. K. Bowyer and G. I. Paton (2003). Antimony bioavailability in mine soils. Environmental Pollution, 124, 93-100.

Guo, T., R. D. DeLaune and W.H. Patrick, Jr. (1997). The influence of sediment redox chemistry on chemically active forms of arsenic, cadmium, chromium and zinc in estuarine sediment. Environment International, 23(3), 305-316.

Hursthouse, A. S. (2001). The relevance of speciation in the remediation of soils and sediments by metallic elements - an overview and examples from Central Scotland, UK. Journal of Environmental Monitoring, 3, 49-60.

Imrie, C. E., A. Korre, G. Munoz-Melendez, I. Thornton and S. Durucan (2008). Application of factorial kriging analysis to the FOREGS European topsoil geochemistry database. Science of the Total Environment, 393, 96-110.

Jordan, C., C. Zhang and A. Higgins (2007). Using GIS and statistics to study influences of geology on probability features of surface soil geochemistry in Northern Ireland. Journal of Geochemical Exploration, 93, 135-152.

Jordan, C., A. Higgins, K. Hamill and J.G. Cruickshank (2001). The Soil Geochemical Atlas of Northern Ireland. Department of Agriculture and Rural Development, NI.

Konen, M. E., P. M. Jacobs, C. L. Burras, B. J. Talaga and J. A. Mason (2002). Equations for predicting soil organic carbon using loss-on-ignition for North Central U.S. Soils. Soil Science Society of America Journal, 66(6), 1878-1881.

Laveuf, C., S. Cornu, D. Baize, M. Hardy, O. Josiere, S. Drouin, A. Bruand and F. Juillot (2009). Zinc redistribution in a soil developed from limestone during pedogenesis. Pedosphere, 19(3), 292-304. 
873 Ljung, K., A. Oomen, M. Duits, O. Selinus and M. Berglund (2007). 874 Bioaccessibility of metals in urban playground soils. Journal of Environmental 875 Science and Health Part A, 42, 1241-1250. Lloyd, C. D. (2010). Spatial Data Analysis: An Introduction for GIS Users. 878 Oxford University Press.

880 Ma, J., G. Wei, Y. Xu, W. Long and W. Sun (2007). Mobilisation and 881 redistribution of major and trace elements during extreme weathering of basalt in 882 Hainan Island, South China. Geochimica et Cosmochimica Acta, 71, 3223-3237.

884 Matheron, G. (1965). The theory of regionalised variables and their estimation. 885 Masson, Paris.

Meunier, L., S. R. Walker, J. Wragg, M. B. Parsons, I. Koch, H. E. Jamieson and K. J. Reimer (2010). Effects of soil composition and mineralogy on the bioaccessibility of arsenic from tailings and soil in gold mine districts of Nova Scotia. Environmental Science and Technology, 44, 2667-2674. Foundation. Geological Survey of Northern Ireland, Antrim.

Nathanail, P., C. McCaffrey, M. Ashmore, Y. Cheng, A. Gillett, R. Ogden and D. Scott (2009). The LQM/CIEH Generic Assessment Criteria for Human Health Risk Assessment $2^{\text {nd }}$ ed. Land Quality Press, Nottingham.

Nathanail, C. P. and R. Smith (2007). Incorporating bioaccessibility in detailed quantitative human health risk assessments. Journal of Environmental Science and Health Part A, 42, 1193-1202.

Oomen, A., C. Rompleberg, M. Bruil, C. Dobbe, D. Pereboom and A. Sips (2003). Development of an in vitro digestion model for estimating the bioaccessibility of soil contaminants. Archives of Environmental Contamination and Toxicology, 44, 281-287.

Palumbo-Roe, B. and B. Klinck (2007). Bioaccessibility of arsenic in mine waste-contaminated soils: A case study from an abandoned arsenic mine in SW England (UK). Journal of Environmental Science and Health Part A, 42, 12511261.

Pelfrêne, A., C. Waterlot, M. Mazzuca, C. Nisse, D. Cuny, A. Richard, S. Denys, C. Heyman, H. Roussel, G. Bidar and F. Douay (2012). Bioaccessibility of trace elements as affected by soil parameters in smelter-contaminated agricultural soils: a statistical modelling approach. Environmental Pollution, 160, 130-138.

Poggio, L., B. Vrščaj, R. Schulin, E. Hepperle and F. Marsan (2009). Metals pollution and human bioaccessibility of topsoils in Grugliasco (Italy). Environmental Pollution, 157, 680-689. 
922 Ruby, M., A. Davis, R. Schoof, S. Eberle and C. Sellstone (1996). Estimation of 923 Lead and Arsenic Bioavailability Using a Physiologically Based Extraction Test. 924 Environmental Science \& Technology, 30 (2), 422-430.

Ruby, M., R. Schoof, W. Brattin, M. Goldade, G. Post, M. Harnois, D. Mosby, S. Casteel, W. Berti, M. Carpenter, D. Edwards, D. Cragin and W. Chappell (1999). Advances in Evaluating the Oral Bioavailability of Inorganics in Soil for Use in Human Health Risk Assessment. Environmental Science \& Technology, 33 (21), 3697-3706.

Salehi, M., O. Hashemi Beni, H. Beigi Harchegani, I. Esfandiarpour Borujeni and H. Motaghian (2011). Refining soil organic matter determination by loss-onignition. Pedosphere, 21(4), 473-482.

Smyth, D. (2007). Methods used in the Tellus geochemical mapping of Northern Ireland. British Geological Survey Open Report OR/07/022, 2007.

Sparks, D. (1995). Environmental Soil Chemistry. Academic Press, Inc., New York.

Theng, B. (1974). The Chemistry of Clay Organic Reactions. Halsted Press, New York.

Triola, M. (1998). Elementary Statistics, $7^{\text {th }}$ ed. Addison Wesley Longman, Inc.; USA.

Van De Weile, T., A. Oomen, J. Wragg, M. Cave, M. Minekus, A. Hack, C. Cornelis, C. Rompleberg, L. De Zwart, B. Klinck, J. Van Wijnen, W. Verstraete and A. Sips (2007). Comparison of five in vitro digestion models to in vivo experimental results: Lead bioaccessibility in the human gastrointestinal tract. Journal of Environmental Science and Health Part A, 42, 1203-1211.

Wilson, H. (1972). Regional Geology of Northern Ireland. Geological Survey of Northern Ireland; Her Majesty's Stationery Office, Belfast.

Wragg, J. (2009). BGS Guidance Material 102, Ironstone Soil, Certificate of Analysis: IR/09/006.

Wragg, J. and M. R. Cave (2003). In-vitro Methods for the Measurement of the Oral Bioaccessibility of Selected Metals and Metalloids in Soils: A Critical Review. BGS R\&D Technical Report P5-062/TR/01.

Wragg, J., M. Cave, N. Basta, E. Brandon, S. Casteel, S. Denys, C. Gron, A. Oomen, K. Reimer, K. Tack and T. Van de Wiele (2011). An inter-laboratory trial of the unified BARGE bioaccessibility method for arsenic, cadmium and lead in soil. Science of the Total Environment, 409, 4016-4030.

Wragg, J., M. Cave and P. Nathanail (2007). A study of the relationship between arsenic bioaccessibility and its solid-phase distribution in soils from Wellingborough, UK. Journal of Environmental Science and Health Part A, 1303-1315. 
974 Wragg, J., M. Cave, H. Taylor, N. Basta, E. Brandon, S. Casteel, C. Gron, A. 975 Oomen and T. Van de Wiele (2009). Inter-laboratory trial of a unified 976 bioaccessibility procedure. British Geological Survey Chemical \& Biological 977 Hazards Programme, Open Report OR/07/027.

978

979 Zhang, C., D. Fay, D. McGrath, E. Grennan and O. Carton (2007). Statistical 980 analyses of geochemical variables of soils in Ireland. Geoderma, 146, 378-390. 
Table 1 Summary statistics for BAF (\%) results (from Barsby et al. 2012), total $\mathrm{Ni}, \mathrm{V}, \mathrm{Zn}\left(\mathrm{mg} \mathrm{kg}^{-1}\right)$ and oxide $(\%)$ concentrations

\begin{tabular}{|c|c|c|c|c|c|c|c|c|}
\hline & Min & Max & Mean & St.Dev. & Min & Max & Mean & St.Dev. \\
\hline \multicolumn{5}{|c|}{ Northern Ireland, $\mathrm{n}=6862$} & \multicolumn{4}{|c|}{ Basalt Bedrock Group, $\mathrm{n}=23$} \\
\hline $\mathrm{Ni}$ & 1.40 & 333.60 & 46.21 & 48.65 & 4.90 & 185.30 & 77.66 & 59.65 \\
\hline V & 5.90 & 401.60 & 99.66 & 65.04 & 18.10 & 280.00 & 157.88 & 88.98 \\
\hline $\mathrm{Zn}$ & 2.80 & 2460.50 & 78.35 & 54.29 & 21.40 & 175.70 & 85.78 & 48.11 \\
\hline $\mathrm{MgO}$ & 0.50 & 5.80 & 1.45 & 0.66 & 0.60 & 3.70 & 1.72 & 0.82 \\
\hline $\mathrm{Al}_{2} \mathrm{O}_{3}$ & 3.50 & 17.20 & 10.61 & 2.98 & 4.00 & 14.90 & 10.59 & 3.37 \\
\hline $\mathrm{SiO}_{2}$ & 13.80 & 87.90 & 49.56 & 15.00 & 16.20 & 75.10 & 41.36 & 14.68 \\
\hline $\mathrm{P}_{2} \mathrm{O}_{5}$ & 0.05 & 1.70 & 0.26 & 0.10 & 0.08 & 0.56 & 0.25 & 0.11 \\
\hline $\mathrm{SO}_{3}$ & 0.00 & 2.00 & 0.18 & 0.24 & 0.00 & 0.80 & 0.27 & 0.24 \\
\hline $\mathrm{CaO}$ & 0.30 & 16.33 & 1.15 & 0.78 & 0.41 & 3.10 & 1.66 & 0.72 \\
\hline $\mathrm{MnO}$ & 0.00 & 15.00 & 0.08 & 0.26 & 0.00 & 0.27 & 0.10 & 0.08 \\
\hline $\mathrm{Fe}_{2} \mathrm{O}_{3}$ & 0.30 & 42.25 & 4.65 & 2.85 & 1.26 & 11.42 & 6.26 & 3.34 \\
\hline \multicolumn{5}{|c|}{ Lithic Arenite Bedrock Group, $\mathrm{n}=17$} & \multicolumn{4}{|c|}{ Mudstone Bedrock Group, $\mathrm{n}=18$} \\
\hline $\mathrm{Ni}$ & 21.20 & 72.80 & 41.64 & 14.09 & 13.80 & 153.20 & 47.25 & 38.50 \\
\hline V & 74.50 & 124.30 & 95.55 & 14.46 & 36.40 & 234.10 & 90.82 & 53.46 \\
\hline $\mathrm{Zn}$ & 73.80 & 2460.50 & 242.25 & 572.48 & 41.70 & 151.90 & 83.85 & 33.23 \\
\hline $\mathrm{MgO}$ & 1.10 & 2.80 & 1.71 & 0.40 & 0.70 & 2.60 & 1.40 & 0.54 \\
\hline $\mathrm{Al}_{2} \mathrm{O}_{3}$ & 10.10 & 13.50 & 11.78 & 1.12 & 4.90 & 13.40 & 9.94 & 2.32 \\
\hline $\mathrm{SiO}_{2}$ & 41.10 & 67.60 & 56.84 & 7.80 & 19.60 & 73.30 & 51.09 & 13.09 \\
\hline $\mathrm{P}_{2} \mathrm{O}_{5}$ & 0.15 & 0.48 & 0.31 & 0.09 & 0.18 & 0.55 & 0.28 & 0.09 \\
\hline $\mathrm{SO}_{3}$ & 0.00 & 0.80 & 0.11 & 0.21 & 0.00 & 0.80 & 0.23 & 0.30 \\
\hline $\mathrm{CaO}$ & 0.53 & 2.08 & 0.83 & 0.39 & 0.56 & 3.64 & 1.52 & 0.95 \\
\hline $\mathrm{MnO}$ & 0.04 & 0.19 & 0.08 & 0.04 & 0.03 & 0.27 & 0.09 & 0.06 \\
\hline $\mathrm{Fe}_{2} \mathrm{O}_{3}$ & 2.96 & 6.31 & 4.37 & 0.85 & 1.76 & 10.21 & 4.40 & 2.20 \\
\hline \multicolumn{5}{|c|}{ Bioaccessibility Study Sample Set, $\mathrm{n}=91$} & \multicolumn{4}{|c|}{ Basalt Bedrock Group } \\
\hline $\mathrm{V}-\mathrm{G}$ & 1.92 & 22.50 & 8.72 & 4.59 & 3.82 & 22.50 & 11.19 & 5.65 \\
\hline V-GI & 0.56 & 14.66 & 3.98 & 2.54 & 0.57 & 9.94 & 4.37 & 2.59 \\
\hline $\mathrm{Ni}-\mathrm{G}$ & 1.42 & 43.82 & 12.16 & 9.59 & 1.42 & 43.82 & 12.32 & 12.12 \\
\hline Ni-GI & 0.60 & 14.45 & 5.50 & 2.92 & 0.60 & 9.98 & 4.49 & 2.66 \\
\hline $\mathrm{Zn}-\mathrm{G}$ & 4.28 & 80.76 & 22.17 & 17.63 & 6.92 & 80.76 & 26.85 & 22.42 \\
\hline Zn-GI & 2.47 & 40.28 & 13.25 & 7.86 & 2.91 & 40.28 & 13.43 & 10.13 \\
\hline \multicolumn{5}{|c|}{ Lithic Arenite Bedrock Group } & \multicolumn{4}{|c|}{ Mudstone Bedrock Group } \\
\hline $\mathrm{V}-\mathrm{G}$ & 2.64 & 16.67 & 7.18 & 4.12 & 2.49 & 21.96 & 9.25 & 4.83 \\
\hline V-GI & 0.95 & 8.35 & 3.33 & 2.20 & 1.25 & 14.66 & 4.94 & 3.46 \\
\hline $\mathrm{Ni}-\mathrm{G}$ & 3.01 & 42.17 & 9.87 & 9.77 & 4.13 & 33.62 & 14.50 & 8.71 \\
\hline Ni-GI & 1.27 & 14.45 & 4.31 & 2.88 & 2.65 & 12.07 & 7.06 & 2.63 \\
\hline $\mathrm{Zn}-\mathrm{G}$ & 4.28 & 57.79 & 15.27 & 12.79 & 10.17 & 68.63 & 22.34 & 15.82 \\
\hline Zn-GI & 2.47 & 16.45 & 7.62 & 3.37 & 4.98 & 24.06 & 13.34 & 5.50 \\
\hline
\end{tabular}


Table 2 Pearson's Correlation Coefficients for Selected Geochemical Parameters and UBM Results (UBM data from Barsby et al. 2012)

\begin{tabular}{|c|c|c|c|c|c|c|c|c|c|c|c|c|c|}
\hline & Total V & Total Ni & Total Zn & $\mathrm{MgO}$ & $\mathrm{Al}_{2} \mathrm{O}_{3}$ & $\mathrm{SiO}_{2}$ & $\mathrm{P}_{2} \mathrm{O}_{5}$ & $\mathrm{SO}_{3}$ & $\mathrm{CaO}$ & $\mathrm{MnO}$ & $\mathrm{Fe}_{2} \mathrm{O}_{3}$ & $\mathrm{pH}$ & $\mathrm{SOC}^{2}$ \\
\hline \multicolumn{14}{|c|}{ Bioaccessibility Study Sample Set } \\
\hline V-G & -.164 & -.171 & .127 & $-.331^{* *}$ & $-.556^{* *}$ & $-.379^{* *}$ & -.178 & $.542^{* *}$ & .121 & $-.414^{* *}$ & $-.353^{* *}$ & -.143 & $.517^{* *}$ \\
\hline V-GI & $-.288^{* *}$ & $-.305^{* *}$ & .125 & $-.413^{* *}$ & $-.530^{* *}$ & -.134 & -.029 & $.395^{* *}$ & .078 & $-.448^{* *}$ & $-.473^{* *}$ & .022 & $.294^{* *}$ \\
\hline $\mathrm{Ni}-\mathrm{G}$ & $-.447^{* *}$ & $-.293^{* *}$ & $.298^{* *}$ & $-.511^{* *}$ & $-.696^{* *}$ & $-.536^{* * *}$ & -.163 & $.754^{* *}$ & .006 & $-.396^{* *}$ & $-.484^{* *}$ & $-.310^{* *}$ & $.723^{* *}$ \\
\hline Ni-GI & $-.511^{* *}$ & $-.366^{* * *}$ & $.296^{* *}$ & $-.543^{* *}$ & $-.516^{* *}$ & -.102 & -.080 & $.428^{* *}$ & -.090 & $-.355^{* *}$ & $-.531^{* *}$ & -.057 & $.269^{* *}$ \\
\hline $\mathrm{Zn}-\mathrm{G}$ & $-.433^{* *}$ & $-.291^{* * *}$ & .182 & $-.479^{* *}$ & $-.805^{* *}$ & $-.605^{\text {** }}$ & -.177 & $.727^{* *}$ & .124 & $-.389^{* *}$ & $-.462^{* *}$ & $-.294^{* *}$ & $.810^{\text {** }}$ \\
\hline Zn-GI & $-.582^{* *}$ & $-.550^{* *}$ & -.071 & $-.661^{* *}$ & $-.707^{* *}$ & $-.207^{*}$ & $-.331^{* *}$ & $.376^{* *}$ & -.199 & $-.586^{* *}$ & $-.619^{* *}$ & $-.325^{* *}$ & $.446^{* *}$ \\
\hline \multicolumn{14}{|c|}{ Basalt Bedrock Group } \\
\hline V-G & $-.533^{* *}$ & $-.606^{* *}$ & $-.638^{* *}$ & $-.612^{* *}$ & $-.679^{* *}$ & -.410 & $-.581^{* *}$ & $.606^{* *}$ & -.251 & $-.736^{* *}$ & $-.690^{* *}$ & $-.532^{* *}$ & $.626^{* *}$ \\
\hline V-GI & $-.510^{*}$ & $-.696^{* *}$ & $-.709^{* *}$ & $-.676^{* *}$ & $-.593^{* *}$ & -.138 & $-.547^{* *}$ & .394 & -.355 & $-.766^{* *}$ & $-.736^{* *}$ & $-.473^{*}$ & .406 \\
\hline $\mathrm{Ni}-\mathrm{G}$ & $-.749^{* *}$ & $-.611^{* *}$ & $-.682^{* *}$ & $-.712^{* *}$ & $-.826^{* *}$ & $-.552^{* *}$ & $-.563^{* *}$ & $.677^{* *}$ & $-.570^{* *}$ & $-.651^{* *}$ & $-.718^{* *}$ & $-.696^{* *}$ & $.811^{* *}$ \\
\hline Ni-GI & $-.784^{* *}$ & $-.700^{* * *}$ & $-.757^{* *}$ & $-.710^{* *}$ & $-.607^{* *}$ & -.048 & $-.591^{* *}$ & .214 & $-.689^{* *}$ & $-.695^{* *}$ & $-.789^{* *}$ & $-.426^{*}$ & .390 \\
\hline $\mathrm{Zn}-\mathrm{G}$ & $-.761^{* *}$ & $-.600^{* * *}$ & $-.676^{* *}$ & $-.691^{* *}$ & $-.890^{* *}$ & $-.563^{* *}$ & $-.588^{* *}$ & $.724^{* *}$ & $-.555^{* *}$ & $-.649^{* *}$ & $-.713^{* *}$ & $-.743^{* *}$ & $.854^{* *}$ \\
\hline Zn-GI & $-.828^{* *}$ & $-.751^{* *}$ & $-.834^{* *}$ & $-.824^{* *}$ & $-.828^{* *}$ & -.222 & $-.655^{* *}$ & $.451^{*}$ & $-.762^{* *}$ & $-.763^{* *}$ & $-.833^{* *}$ & $-.685^{* *}$ & $.605^{\text {** }}$ \\
\hline \multicolumn{14}{|c|}{ Lithic Arenite Bedrock Group } \\
\hline V-G & -.121 & -.018 & -.140 & -.294 & $-.723^{* *}$ & $-.493^{*}$ & .054 & $.775^{* *}$ & .083 & -.431 & $-.591^{*}$ & -.165 & $.641^{* *}$ \\
\hline V-GI & -.231 & -.104 & -.177 & -.334 & $-.673^{* *}$ & -.430 & .170 & $.764^{\text {** }}$ & .055 & -.441 & $-.652^{* *}$ & -.133 & $.607^{* *}$ \\
\hline $\mathrm{Ni}-\mathrm{G}$ & $\begin{array}{r}.329 \\
-.329\end{array}$ & -.251 & -.148 & -.322 & $-.552^{*}$ & $-.585^{*}$ & -.309 & $.943^{* *}$ & -.217 & -.306 & $-.510^{*}$ & -.407 & $.806^{* *}$ \\
\hline Ni-GI & -.345 & -.261 & -.150 & -.398 & $-.543^{*}$ & -.383 & -.284 & $.892^{* * *}$ & -.291 & -.274 & $-.559^{*}$ & -.328 & $.649^{\text {** }}$ \\
\hline $\mathrm{Zn}-\mathrm{G}$ & -.381 & -.327 & -.237 & -.324 & $-.567^{*}$ & $-.529^{*}$ & -.119 & $.952^{* *}$ & -.193 & -.213 & $-.529^{*}$ & -.382 & $.756^{\text {** }}$ \\
\hline Zn-GI & $-.527^{*}$ & $-.506^{*}$ & -.412 & -.358 & $-.556^{*}$ & -.445 & .087 & $.842^{\text {** }}$ & .007 & -.299 & $-.602^{*}$ & -.076 & $.666^{\text {** }}$ \\
\hline \multicolumn{14}{|c|}{ Mudstone Bedrock Group } \\
\hline V-G & -.299 & -.196 & -.182 & $-.501^{*}$ & $-.730^{* *}$ & -.145 & .257 & .421 & .436 & $-.500^{*}$ & -.435 & .463 & .387 \\
\hline V-GI & -.434 & -.330 & -.263 & $-.532^{*}$ & $-.827^{* *}$ & -.118 & .308 & .378 & .415 & $-.505^{*}$ & $-.558^{*}$ & $.474^{*}$ & .399 \\
\hline $\mathrm{Ni}-\mathrm{G}$ & -.264 & -.136 & .010 & -.456 & $-.652^{* *}$ & $-.750^{* *}$ & .351 & $.925^{* *}$ & $.724^{* * *}$ & -.405 & -.364 & .121 & $.871^{* * *}$ \\
\hline Ni-GI & -.356 & -.241 & -.066 & -.403 & $-.550^{*}$ & -.360 & .144 & $.719^{* *}$ & .432 & -.381 & -.449 & .196 & $.501^{*}$ \\
\hline $\mathrm{Zn}-\mathrm{G}$ & -.345 & -.225 & .034 & -.360 & $-.753^{* *}$ & $-.645^{\text {** }}$ & .438 & $.637^{* *}$ & $.756^{* *}$ & -.380 & -.428 & .393 & $.854^{* *}$ \\
\hline Zn-GI & $-.717^{* *}$ & $-.658^{* *}$ & $-.560^{*}$ & $-.607^{* *}$ & $-.878^{* *}$ & -.131 & .250 & .304 & .268 & $-.658^{* *}$ & $-.834^{* *}$ & .358 & .381 \\
\hline
\end{tabular}

$* *$ Correlation is significant at the 0.01 level (2-tailed)

*Correlation is significant at the 0.05 level (2-tailed)

${ }^{2}$ As estimated by loss on ignition 


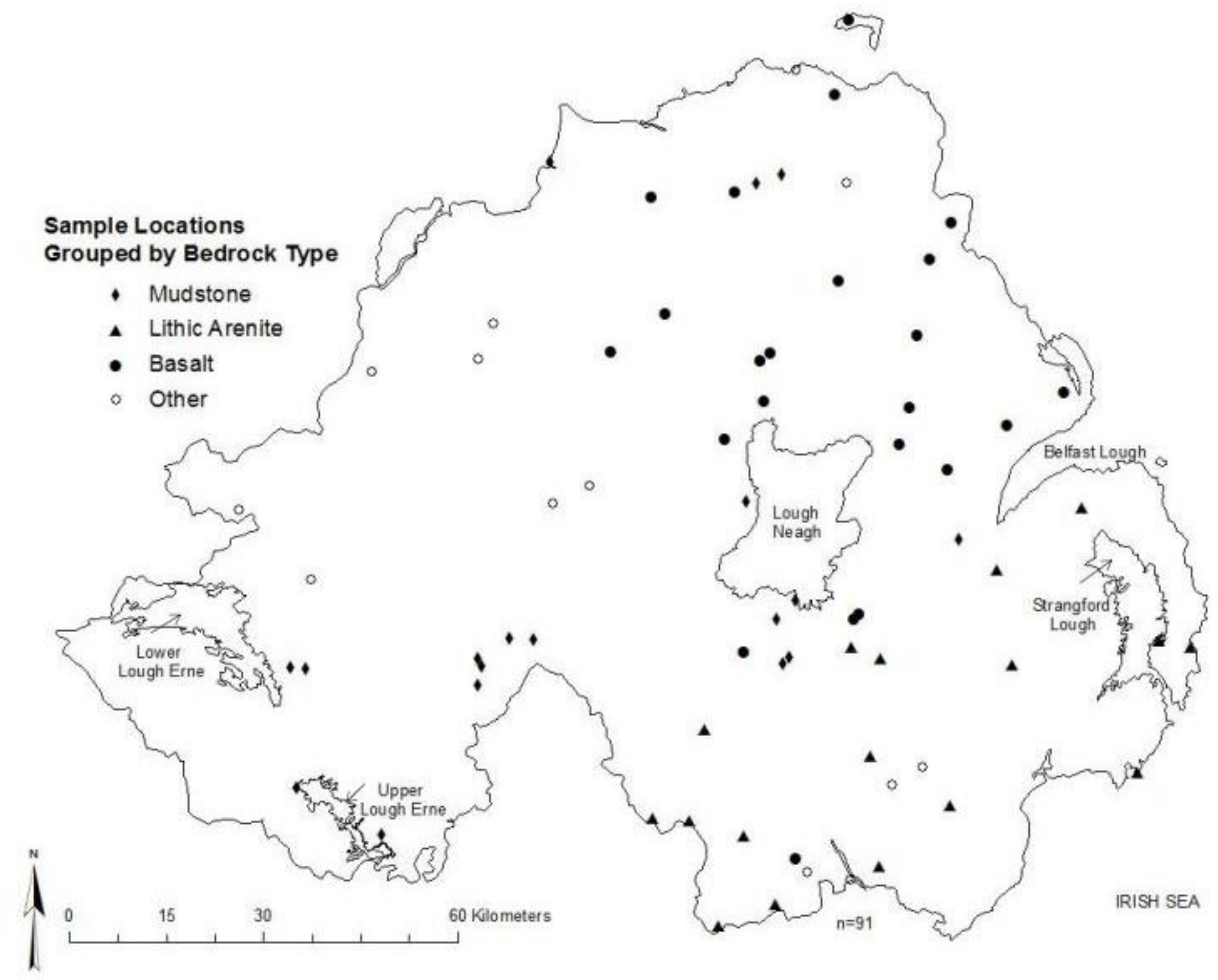

Fig. 1 Northern Ireland soil sample location map for bioaccessibility testing with bedrock classification 
A)

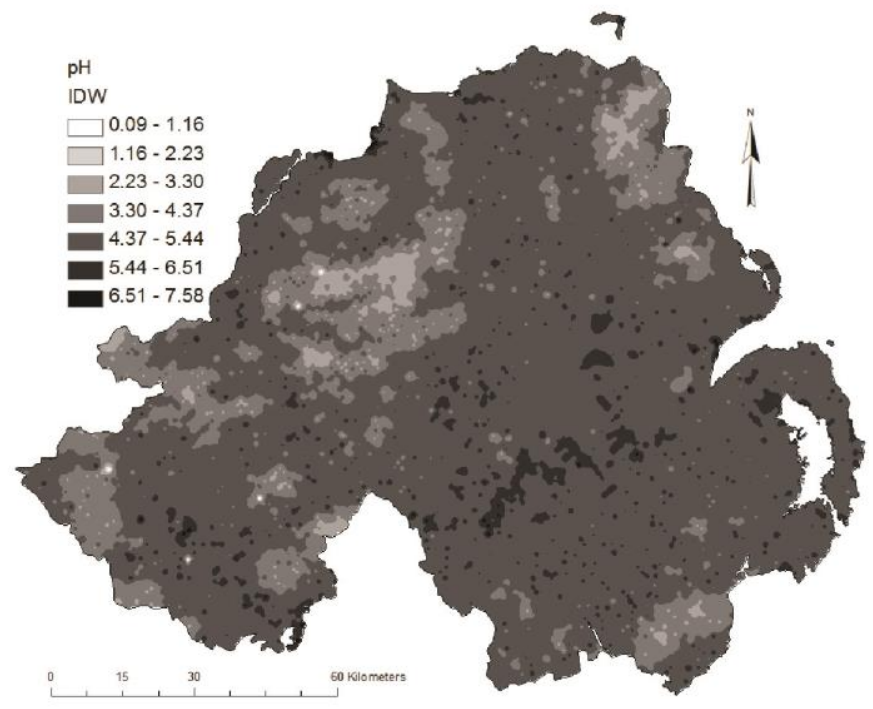

C)

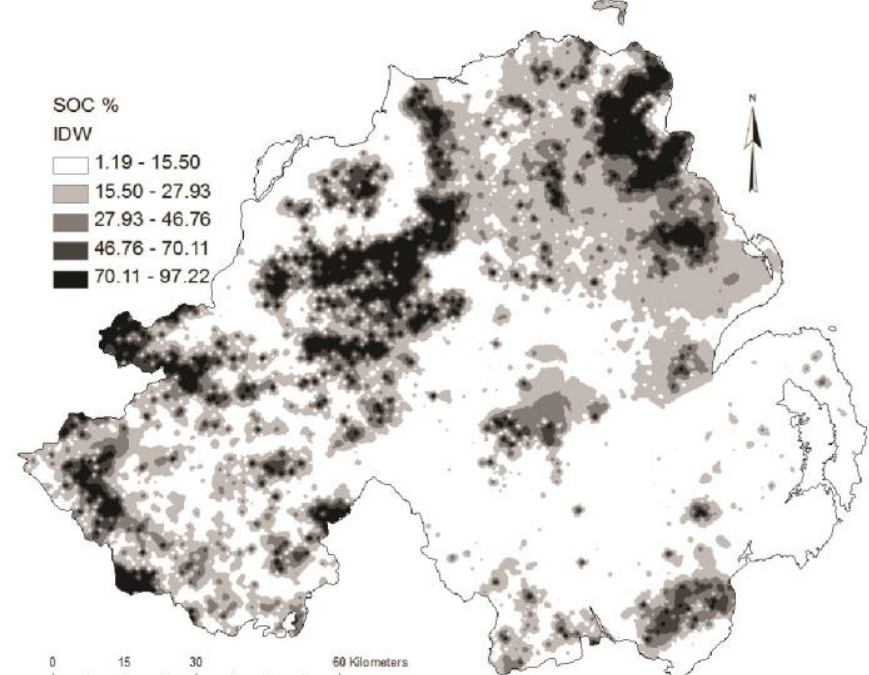

B)

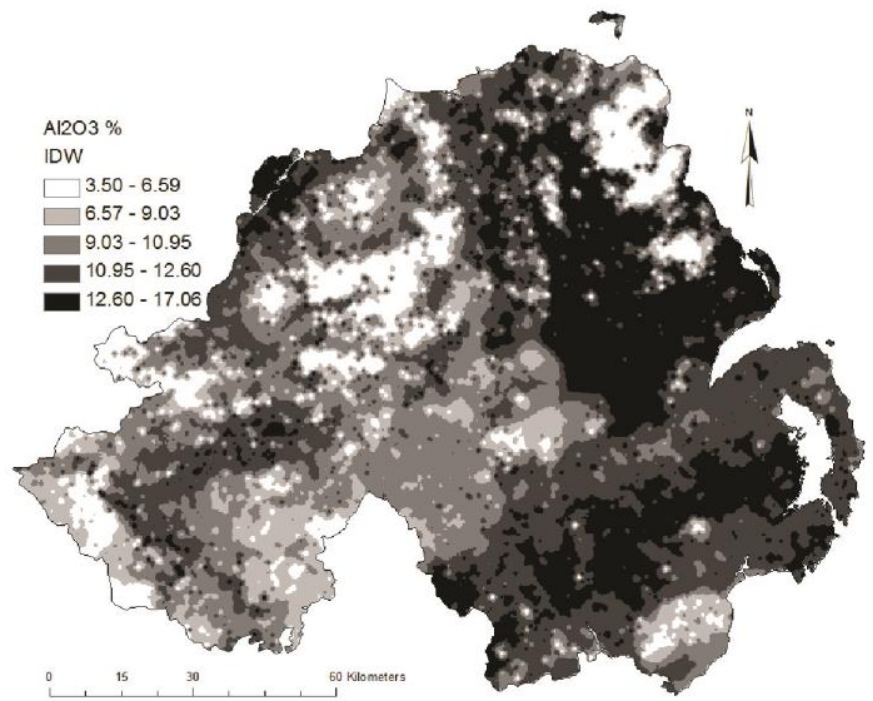

D)

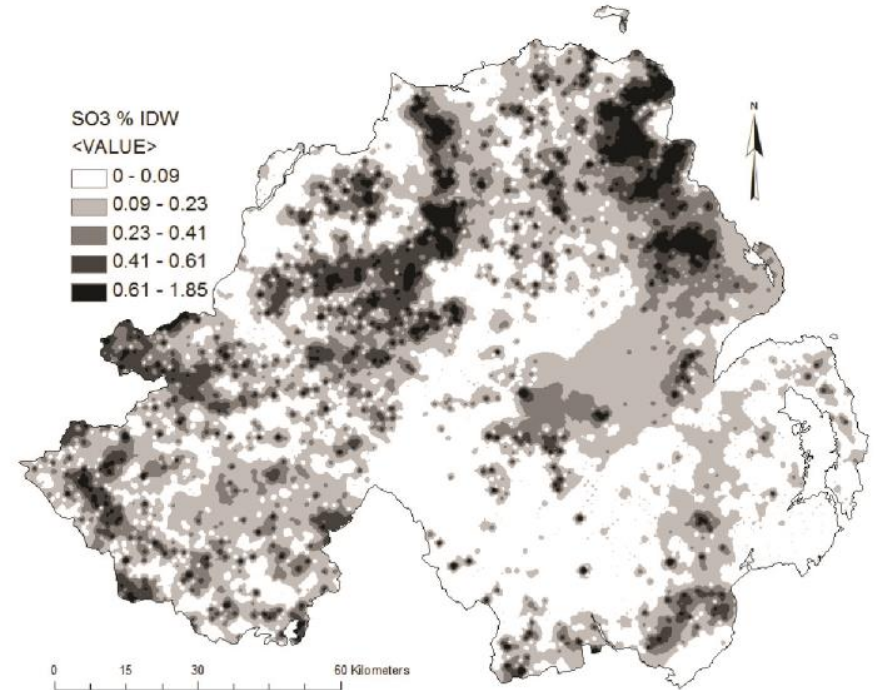

Fig. $2 \mathrm{pH}, \mathrm{Al}_{2} \mathrm{O}_{3}, \mathrm{SO}_{3}$ and estimated SOC interpolated by IDW, 12 neighbours, showing highest and lowest proportional distributions and acidity in areas of upland peat deposits across Northern Ireland 


\section{Supporting Information:}

Table A. Skewness and kurtosis values for Ni, V and Zn, demonstrating a general increase towards a normal distribution after bedrock group sub-division

\begin{tabular}{lcc}
\hline & Skewness & Kurtosis \\
\hline V N. Ireland & 1.00 & 0.50 \\
V Study Set & 1.18 & 0.56 \\
V Basalt & -0.24 & -1.43 \\
V Lithic Arenite & 0.29 & -0.57 \\
V Mudstone & 1.30 & 1.5 \\
\hline Ni N. Ireland & 1.89 & 3.66 \\
Ni Study Set & 1.98 & 4.01 \\
Ni Basalt & 0.57 & -0.90 \\
Ni Lithic Arenite & 0.67 & -0.15 \\
Ni Mudstone & 1.20 & 0.12 \\
\hline Zn N. Ireland & 14.28 & 556.89 \\
Zn Study Set & 8.97 & 83.44 \\
Zn Basalt & 0.27 & -1.02 \\
Zn Lithic Arenite & 1.60 & 2.50 \\
Zn Mudstone & 0.73 & -0.44 \\
\hline
\end{tabular}

N. Ireland values, $n=68 \overline{82 ; \text { study set, } n=91 ; \text { basalt, } n=23 \text {; lithic arenite, } n}=17$; mudstone, $n=18$ 